\title{
Gender stereotypes in equity crowdfunding: the effect of gender bias on the interpretation of quality signals
}

\author{
Simon Kleinert ${ }^{1}$ D $\cdot$ Kazem Mochkabadi $^{2}$
}

Accepted: 29 September 2021 / Published online: 11 October 2021

(C) The Author(s) 2021

\begin{abstract}
Equity crowdfunding has the potential to democratize entrepreneurial finance and provide female entrepreneurs with new and equal access to early-stage financing. In this paper, we present first empirical evidence on gender stereotypes in the context of technology ventures in equity crowdfunding. Drawing on signaling and gender role congruity theory, we hypothesize that quality signals have different effects depending on whether they are sent by male or female entrepreneurs. Results taken from a sample of 263 equity crowdfunding campaigns run by technology ventures confirm our hypotheses. In line with gender stereotypes, management experience is beneficial for male entrepreneurs but detrimental for female entrepreneurs. Interestingly, media coverage as a third-party signal has the oppositive effect, being more effective for female entrepreneurs.
\end{abstract}

Keywords Equity financing · Gender · Signaling theory · Gender role congruity theory · Equity crowdfunding

JEL Classification $\mathrm{G} 23 \cdot \mathrm{G} 30 \cdot \mathrm{L} 26$

\section{Introduction}

Equity financing is a prerequisite for the growth of any new venture. However, many entrepreneurs fail to raise the necessary funding at an early stage (Cumming \& Vismara, 2017). Access to equity financing is particularly problematic for female entrepreneurs, who are $63 \%$ less likely to raise equity funding than their male counterparts (Guzman \& Kacperczyk, 2019). One of the main reasons for this discrimination against women is that conventional equity financing comes mainly from male-dominated sources, such as venture capital and business angels (Brush et al., 2018; Harrison \& Mason, 2007). Over the last decade, equity crowdfunding has developed as a viable financing alternative (Block et al.,

Simon Kleinert

s.kleinert@maastrichtuniversity.nl

Kazem Mochkabadi

mochkabadi@wiwi.uni-wuppertal.de

1 Maastricht University, Tongersestraat 53, 6211 LM Maastricht, Netherlands

2 University of Wuppertal, Gaußstr. 20, 42119 Wuppertal, Germany 
2018a; Butticè \& Vismara, 2021), enabling entrepreneurs to sell equity shares to a crowd of often unaccredited investors (Ahlers et al., 2015; Kleinert et al., 2021). This new form of equity financing could be a "game-changer" as it offers the potential to democratize entrepreneurial finance for female entrepreneurs, as well as for other underrepresented groups (Cumming et al., 2019; Vismara et al., 2017).

It is unclear whether equity crowdfunding can overcome the gender gap in entrepreneurial finance, and initial empirical evidence provides mixed results on the role of gender in equity crowdfunding. Observational data from US equity crowdfunding campaigns indicates that female-led ventures raise significantly less funding, and this effect is amplified for larger campaigns (Geiger \& Oranburg, 2018). In contrast, recent experimental evidence shows that the crowd does not discriminate against female entrepreneurs and that equity crowdfunding could indeed have the potential to close the gender gap apparent in conventional markets for equity financing (Bapna \& Ganco, 2020). However, given the recent nature of gender studies in equity crowdfunding, several important contingencies have not yet been considered. The limited access by female entrepreneurs to equity financing in conventional capital markets is often associated with the industry in which the female entrepreneurs operate (Guzman \& Kacperczyk, 2019). For instance, while ventures headed by female executives accounted for $15 \%$ of all venture capital investments in the US between 2011 and 2013, they accounted for only $2 \%$ of investment in biotechnology, 5\% of investment in software, and 2\% of investment in business products (Brush et al., 2018). Equity crowdfunding facilitates funding for diverse industries, ranging from conventional businesses such as restaurants and retail to high-growth technology ventures; still, the technology sector represents the largest chunk of funding amounts (Bapna, 2019). Accordingly, it is essential to consider not only how female entrepreneurs generally perform in equity crowdfunding, but also specifically, how successful they are in raising funds in the maledominated technology sector (Johnson et al., 2018).

It is also conceivable that investors in equity crowdfunding do not simply prefer campaigns by male entrepreneurs to those by female entrepreneurs, and do not consciously discriminate against women (Bapna \& Ganco, 2020); instead, investors might unconsciously interpret information based on the entrepreneur's gender. The way in which signals about a new venture's quality and its entrepreneurial capabilities are interpreted is particularly important for entrepreneurs seeking to raise funds (Ahlers et al., 2015; Vismara, 2016, 2018). Crowd investors might only react to such signals if they are congruent with the sender's social role and a stereotypical interpretation of signals could prevent female entrepreneurs from demonstrating quality, which could negatively affect their performance in equity crowdfunding.

We combine signaling theory (Spence, 1973) and gender role congruity theory (GRCT) (Eagly \& Karau, 2002), an extension of social role theory (Eagly, 1987), to examine the success of female entrepreneurs in technology ventures in securing equity crowdfunding. Signaling theory claims that new ventures can convey their unobservable quality to outsiders via costly and observable signals (Connelly et al., 2011), while GRCT asserts that information is processed based on gender stereotypes, meaning that information is processed more favorably when men and women behave according to their stereotypical gender roles (Eagly \& Karau, 2002). We start by examining two potentially important quality signals that new technology ventures use for investors in equity crowdfunding to overcome information asymmetries: management experience (Ko \& McKelvie, 2018) and media coverage (Scheaf et al., 2018). Crucially, by combining GRCT and signaling theory, we then propose that management experience constitutes a signal that fits with the male stereotype of leadership skills and assertiveness. We speculate that the signaling effect of management 
experience is contingent on gender, with the result that it is interpreted less positively when sent by women and more positively when sent by men. We further propose that in line with gender expectations about women's high level of trustworthiness (Johnson et al., 2018), female entrepreneurs will benefit more from media coverage as a signal about trustworthiness than male entrepreneurs.

We test our theory with observational data from Crowdcube- a dominant equity crowdfunding portal used in previous studies (e.g., Kleinert et al., 2020; Vismara, 2016) and draw on a unique sample of 263 technology projects. Our study makes important contributions to the body of equity crowdfunding research and access to entrepreneurial finance by female entrepreneurs. By combining signaling theory and GRCT in equity crowdfunding, we show how the benefits gained from quality signals vary depending on the gender of the signal sender. As such, our study offers first evidence that the signaling process in equity crowdfunding is indeed gendered. For example, our research suggests that established quality signals, such as management experience, exclusively benefit male entrepreneurs; this indicates that the interpretation of quality signals (e.g., Ahlers et al., 2015; Kleinert et al., 2020; Vismara, 2016) is not always rational and can be distorted by gender bias. However, our results also point out that gender bias can be advantageous for female entrepreneurs. Media coverage, for example, is a signal that is more valuable for female entrepreneurs than for male entrepreneurs in terms of generating equity crowdfunding.

In addition, our findings contribute to an improved understanding of the democratization and role of gender in equity crowdfunding (Butticè \& Vismara, 2021; Cumming et al., 2019) by disentangling the mixed results of previous studies (e.g., Bapna \& Ganco, 2020; Geiger \& Oranburg, 2018; Vismara et al., 2017). In contrast to previous studies, we focus on the technology sector-its male dominance makes it a relevant context in which to examine the performance of female entrepreneurs (Brush et al., 2018). A central promise of equity crowdfunding is its potential to be a "game-changer" by increasing access to external capital for female entrepreneurs (e.g., Bapna \& Ganco, 2020). We offer the new finding that equity crowdfunding can only partially fulfil this promise for female founders of technology ventures; while our findings suggest that female entrepreneurs generally have a lower chance of success in generating funding than their male counterparts, this success is not contingent on gender but is, in fact, contingent on how signals from women are interpreted. This can work in both directions, either to the benefit or to the detriment of female entrepreneurs.

\section{Theoretical background}

\subsection{Signaling theory in an entrepreneurial finance setting}

Information asymmetries are a key concern in entrepreneurial finance settings. Entrepreneurs possess information about themselves and their opportunities that potential finance providers lack. Consequently, potential finance providers face high risks when choosing new ventures to support because entrepreneurs could be acting opportunistically or lack the capability to turn a new venture into a successful company (Shane \& Cable, 2002). Signaling theory (Spence, 1973) is an established and influential theoretical lens for understanding how entrepreneurs can reduce information asymmetries with potential finance providers (Drover et al., 2018; Plummer et al., 2016). The core concept of signaling theory is that financiers can infer a new venture's quality from observable and costly signals 
(Colombo et al., 2019). Since new ventures of higher quality can obtain credible signals at a lower cost than lower quality ventures, signals will correlate to a new venture's unobservable quality. Entrepreneurial finance literature has extensively used signaling theory to demonstrate how entrepreneurs and new ventures can attract various types of investors, including IPO investors (Mousa \& Reed, 2013), venture capitalists (Islam et al., 2018), banks (Eddleston et al., 2016), or the crowd (Ahlers et al., 2015). A distinction is made between the types of signals that entrepreneurs and new ventures can transmit: internal and third-party signals (e.g., Colombo et al., 2019). Relevant internal signals include the entrepreneur's human capital (e.g., Higgins \& Gulati, 2006; Ko \& McKelvie, 2018), corporate governance characteristics (e.g., Certo, 2003), and intellectual property rights (Hsu \& Ziedonis, 2013). Third-party signals relate to endorsements by external parties such as a new venture's affiliation with prominent partners (Colombo et al., 2019), positive sentiments from customers (Courtney et al., 2017) or coverage in media (Scheaf et al., 2018).

\subsection{Signaling theory in equity crowdfunding}

While information asymmetries play a vital role in all entrepreneurial finance settings, they are particularly acute in equity crowdfunding (Cerpentier et al., 2021; Vismara, 2016). Equity crowdfunding is a novel form of new venture financing (Block et al., 2018a) in which a crowd of often small amateur investors acquires company shares in new and risky ventures via mediating online platforms (Kleinert et al., 2021). A study into different investor types in equity crowdfunding shows that most crowd investors are casual investors who invest small amounts and are relatively risk averse (Goethner et al., 2020). In contrast to professional investors, such as venture capitalists, these small investors are particularly prone to information asymmetries because they lack the financial resources, capabilities, and incentives to perform extensive due diligence of a new venture (Vulkan et al., 2016). For this reason, investors in equity crowdfunding place particular weight on factors that are easy to observe and evaluate (Shafi, 2019). Accordingly, signaling theory is acutely relevant in the equity crowdfunding context (Mochkabadi \& Volkmann, 2020), and a growing number of studies demonstrate that new ventures must send credible signals to attract crowd investors. Ahlers et al. (2015) and Piva and Rossi-Lamastra (2018) indicate that internal signals, such as the number of board members and their entrepreneurial experience and education, serve as quality signals and increase the chances of funding success in equity crowdfunding. Furthermore, Block et al. (2018b) show that entrepreneurs who post updates during their equity crowdfunding campaigns attract investors to their projects. Di Pietro et al. (2020) compare the effects of past achievements as costly signals with cheap talk in equity crowdfunding; their results highlight that past achievements matter while cheap talk can be detrimental for funding success. Vismara (2016) shows that an entrepreneur's social capital and willingness to invest in their own project, i.e., to retain more equity, can establish credibility and signal quality to investors. Kleinert et al. (2020) demonstrate that third-party signals are also crucial in equity crowdfunding. New ventures that have previously raised funding from venture capitalists or business angels are more likely to have successful equity crowdfunding campaigns. Kleinert and Volkmann (2019) study the role of investor discussion boards and show that investor-initiated discussions can serve as third-party quality signals and stimulate funding success.

Despite our increased understanding of the important role of quality signals for funding success in equity crowdfunding, we know little about how potential investors interpret signals from different entrepreneurs. To provide insights on how the signaling process may 
be indeed gendered in an equity crowdfunding context, we first provide two baseline replication hypotheses on internal and third-party signals, upon which our gender moderation is based; a process which is warranted before examining potential moderation effects (e.g., Cesario, 2014; Davidsson, 2016).

\subsection{Hypotheses}

\subsubsection{Management experience}

Human capital is generally recognized as one of the most important success factors for young companies (Unger et al., 2011). Therefore, it is not surprising that early-stage investors also perceive management skills and experience as the most important selection criterion (Zacharakis \& Meyer, 2000). Higher human capital relates to the higher capabilities of entrepreneurs to identify and exploit opportunities (Shane \& Venkataraman, 2000) and translates into a good predictor of future venture performance (Baum \& Silverman, 2004).

Human capital is also widely acknowledged as a costly signal (Spence, 1973), as lower quality individuals are less likely to obtain leadership positions and management experience. In equity crowdfunding, human capital is also observable because ventures provide detailed team descriptions. The importance of human capital as an internal quality signal has also been documented in equity crowdfunding; education and experience can significantly increase the chances of equity crowdfunding success (Ahlers et al., 2015; Piva \& Rossi-Lamastra, 2018). Shafi (2019) considers standardized ratings of equity crowdfunding project descriptions and demonstrates that the rating of the management team is one of the most influential success factors for crowd investors; it is more important, for example, than the ratings of the product and financials. Since new ventures in equity crowdfunding usually lack track records (Di Pietro et al., 2020), potential investors are likely to put particular emphasis on the quality of the team as an indicator of future success potential. This effect may be amplified in the context of technology companies introducing new technologies, which are often unfamiliar to the crowd investor. Consequently, human capital could be even more important in technology companies than in less knowledge-intensive environments (Bosma et al., 2004).

Baseline Hypothesis 1 The entrepreneurs' management experience will increase equity crowdfunding campaign success in the technology sector.

\subsubsection{Media coverage}

Third-party endorsement is another crucial success factor for new ventures and is considered a critical selection criterion by early-stage investors (Courtney et al., 2017). Media coverage as an essential form of third-party endorsement can help new ventures, including new technologies (Scheaf et al., 2018), to gain a positive profile. This can help to reduce uncertainty among investors, increase the perceived trustworthiness of the new venture and entrepreneur in the eyes of stakeholders (Rindova et al., 2007), and increase the perception of the investment as being legitimate (Petkova et al., 2013). Media coverage constitutes a costly signal (Scheaf et al., 2018) as media institutions are selective in terms of the issues they cover; high-quality ventures that have dedicated time and money to create innovations or networks are the most likely to attract media coverage (Deephouse, 2000). It is also 
an observable signal since new ventures in equity crowdfunding report key achievements, such as media coverage, in their project descriptions.

We argue that media coverage, as a third-party quality signal, is critical for technology ventures in equity crowdfunding. Technology ventures often involve speculative development projects with high uncertainties as their products are years away from being brought to market (Haeussler et al., 2014). They also use unfamiliar technologies with long development times. Media coverage can partially resolve this uncertainty, as an independent voice validates the entrepreneurial offering and signals trustworthiness (Scheaf et al., 2018). In equity crowdfunding, investors typically lack the expertise to evaluate complex and technical information (Shafi, 2019); in this regard, media coverage can help to clarify value propositions and make complex information understandable to the general public. Media coverage also serves as an essential milestone in the development process of new ventures: a broad audience becomes aware of the new venture, which helps it to gain market traction and stand out from other projects (Vanacker et al., 2020). We propose that media coverage has a signaling effect on investors.

Baseline Hypothesis 2 Media coverage will increase equity crowdfunding campaign success in the technology sector.

\subsubsection{Gender role congruity theory}

As the interpretation of entrepreneurs' signals depends on the receivers' cognitive abilities to translate them into perceived meaning (Connelly et al., 2011; Park \& Mezias, 2005), signal interpretation is highly susceptible to cognitive bias (e.g., Eddleston et al., 2016). One of the most significant factors is gender stereotyping (e.g., Kelley et al., 2011). To explore how the gender of capital-seeking entrepreneurs influences the equity crowdfunding success, we draw on GRCT (Eagly \& Karau, 2002).

As an extension of social role theory (Eagly, 1987), GRCT considers the congruity of typical gender roles with other roles, e.g., roles associated with leadership positions (Eagly $\&$ Karau, 2002). Gender roles are established, consensual beliefs about stereotypical characteristics associated with men and women. Traditionally, gender roles assign men to high status and leadership-oriented roles (the breadwinner), while women are commonly associated with low-status, subordinate roles (the caretaker) (e.g., Powell \& Eddleston, 2015; Wood \& Eagly, 2010). More precisely, women are typically ascribed communal characteristics (e.g., being helpful, kind, gentle, and nurturing), while men are typically associated with agentic attributes (e.g., confidence, independence, and dominance) (Powell \& Graves, 2003). GRCT builds on these stereotypical gender roles and proposes that men and women are expected to behave according to their gender roles in order to maintain role congruity (Eagly \& Karau, 2002). In brief, GRCT suggests that if an individual acts in line with his or her expected gender role (i.e., is role congruent), the individual will be viewed more favorably than if the expected gender role is violated (i.e., is role incongruent). GRCT specifically explains why women, when they hold positions of power (i.e., leadership roles), are more likely than men to encounter disadvantages due to perceived stereotypical gender role violation (e.g., Carli \& Eagly, 2011; Eagly \& Chin, 2010; Paustian-Underdahl et al., 2014). Therefore, gender stereotypes function as consensual cognitive shortcuts that influence how receivers interpret information for their own decision-making (e.g., Eddleston et al., 2016; Heilman, 2001). As such, gender stereotypes can affect the interpretation of signals by individuals (e.g., Alsos \& Ljunggren, 2017). 
A growing body of research applies GRCT to entrepreneurial finance contexts (e.g., Eddleston et al., 2016; Guzman \& Kacperczyk, 2019; Yang et al., 2020), showing that female entrepreneurs tend to face greater difficulties in signaling venture quality to external capital providers; a result based on the perceived incongruity between the female gender role and the expected gendered understanding of the entrepreneur. As the entrepreneurial role is more likely to be associated with stereotypical masculine (agentic) attributes (e.g., Thébaud, 2015; Gupta et al., 2009), investors apply a gender filter when evaluating signals and signalers, which traditionally leads to a mismatch between women and the stereotypical entrepreneurial ideal (e.g., Alsos \& Ljunggren, 2017; Yang et al., 2020). Since equity crowdfunding investors differ significantly from more professional entrepreneurial finance investors (e.g., Goethner et al., 2020), they may be particularly prone to stereotypical bias. Equity crowdfunding investors are a relatively unsophisticated and inexperienced investor group who often lack the financial resources and expertise needed to perform thorough due diligence (e.g., Kleinert et al., 2020; Vismara, 2016, 2018). Thus, they often make decisions based on simple heuristics (Shafi, 2019) and are, therefore, more likely to be influenced by cognitive shortcuts, i.e., gender stereotypes. In addition, investors in equity crowdfunding evaluate the entrepreneurial offering based on purely digital content without ever having met the founders in person. Taken together, we expect that signal interpretations in equity crowdfunding are subject to gender bias.

2.3.3.1 Management experience and gender In line with GRCT, we propose that management experience provides a signal that corresponds to agentic attributes associated with the stereotypical male entrepreneur. Management experience suggests that the entrepreneur is a confident and independent decision-maker. These characteristics are stereotypically male as opposed to female (Eagly \& Karau, 2002). More precisely, management experience encompasses task-related attributes (e.g., Unger et al., 2011), demonstrating that the entrepreneur is capable of performing necessary generic entrepreneurial activities, which includes implementing strategies and selecting opportunities for business exploitation (e.g., Frese et al., 2007; Shane \& Venkataraman, 2000). As such, management experience indicates that the entrepreneur can successfully function as a strong leader throughout the entrepreneurial process; a road paved with numerous existential problems that need to be solved. As female entrepreneurs are stereotypically associated with communal attributes, signaling management experience violates their gender stereotype. Accordingly, we hypothesize that the positive effect of the management experience signal is stronger for male entrepreneurs than for their female counterparts.

Hypothesis 3 Management experience will increase equity crowdfunding campaign success in the technology sector less for female entrepreneurs than for their male counterparts.

2.3.3.2 Media coverage and gender In accordance with GRCT, we anticipate that media coverage signals will be interpreted more favorably for women than for men. Media coverage fits the communal attributes typically assigned to the social role of women. Namely, gender stereotypes attribute higher trustworthiness to women than to men (Guzman \& Kacperczyk, 2019; Johnson et al., 2018; Zhao et al., 2020). While signaling trustworthiness is generally considered as important in equity crowdfunding (Cholakova \& Clarysse, 2015), it is particularly corresponding to the normative traits and social role expected of women entrepreneurs. Hence, due to their gendered mental model, investors in equity crowdfunding might expect trustworthiness signals from female entrepreneurs. One key dimension of building trust 
involves being featured by a trustworthy third-party such as media institutes. Such media institutes are highly selective and predominantly cover ventures and entrepreneurs that provide worthwhile offerings to external stakeholders (Scheaf et al., 2018). Accordingly, media coverage represents a female congruent signal and we expect it to be more beneficial for female than for male entrepreneurs.

Further, due to stereotypical bias (Eagly \& Karau, 2002), female entrepreneurs generally "face greater difficulties in signaling the quality of their ventures to capital providers" (Eddleston et al., 2016, p. 497). Thus, the often-unsophisticated equity crowdfunding investors may downgrade signals (such as management experience) sent from women. Yet, media coverage constitutes a certification by a credible and independent third-party (Courtney et al., 2017) and it is not related to the internal signal attempts of female entrepreneurs. Media institutes are instead perceived as an objective information mediator (Scheaf et al., 2018) that can generate positive attention for female entrepreneurs who might otherwise remain unnoticed. The effect should be weaker for men, since male founders are stereotypically expected to demonstrate their performance independently (Powell \& Graves, 2003). Consequently, we assume that the positive effect of media coverage is stronger for female entrepreneurs than for their male counterparts.

Hypothesis 4 Media coverage will increase equity crowdfunding campaign success in the technology sector more for female entrepreneurs than for their male counterparts.

Our theoretical model is summarized in Fig. 1.

\section{Method}

\subsection{Sample and data collection}

To test our hypotheses, we used a hand-collected observational dataset from the UKbased equity crowdfunding platform Crowdcube, which is one of the global leading equity crowdfunding platforms frequently used in previous studies (e.g., Butticè et al., 2021; Kleinert et al., 2020; Vismara, 2016). We obtained detailed company-level information, including descriptions of the ventures outlined on the platform, pitch decks, and business plans. Our initial dataset consisted of 445 ventures active on Crowdcube between April

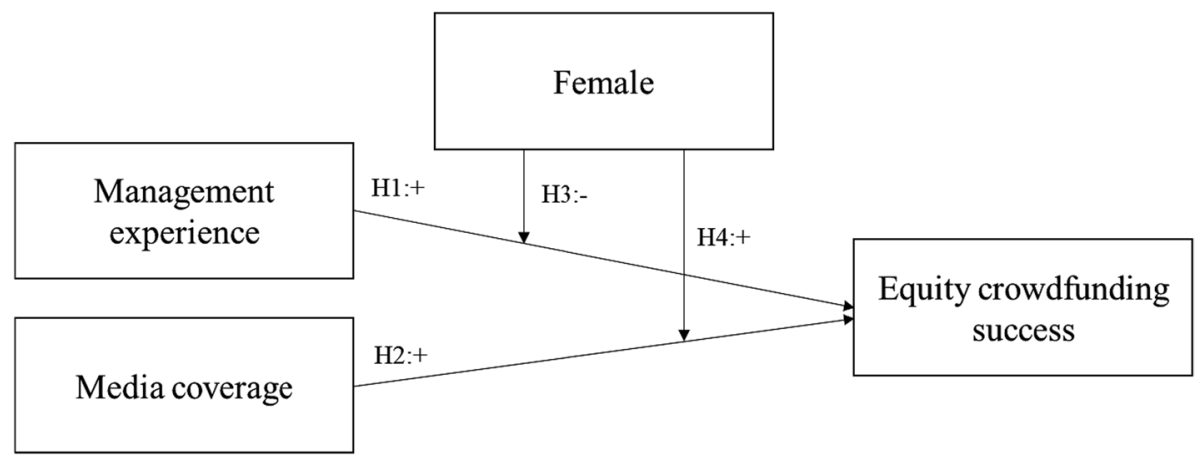

Fig. 1 Theoretical model 
2017 and May 2019. Like most equity crowdfunding platforms, Crowdcube is not limited to specific industries but offers investment opportunities for ventures from various industries, including restaurants, consumer goods, and technology.

In this study, we focus exclusively on technology projects, for several reasons. First, as the funding dynamics usually differ between technology ventures and ventures from other industries (Amit et al., 1998), the comparison of funding success across these different industries is likely to create a bias. A focus on technology ventures as a relevant sector for new ventures has become an appropriate approach to avoid this type of bias (e.g., Ko \& McKelvie, 2018). Second, gender dynamics often differ across industries too, which would complicate the interpretation of gender effects. A frequent observation is that female entrepreneurs struggle to raise funding for technology companies (e.g., Brush et al., 2018); however, the precise origin of this imbalance is less explored (Guzman \& Kacperczyk, 2019). The technology sector is therefore particularly suitable to examine whether equity crowdfunding is a suitable financing channel for women. Third, technology ventures represent a disproportionally large fraction of funding amounts allocated in the equity crowdfunding market (Bapna, 2019). Thus, our focus on the technology sector is also of high practical relevance. Therefore, we excluded ventures operating in non-technology sectors, resulting in a final dataset of 263 ventures. To ensure that our final sample had a clear focus on technology, we only included ventures from the following categories classified by Crowdcube: Automotive, Clean Technology, Fintech, Healthtech \& Healthcare, Life Science \& Biotech, and Consumer Internet.

\subsection{Variables}

Dependent variables: Consistent with prior studies (e.g., Ahlers et al., 2015; Kleinert et al., 2020; Vismara, 2016), we measured campaign success based on two dependent variables, number of investors and amount raised. The number of investors accounts for the total number of equity crowdfunding investors who invested during the campaign, whereas amount raised captures the total amount of funding raised by the end of the campaign.

Independent variables: For our measure of human capital, we identified all the entrepreneurs referred to in the project description; our sample ventures involved mainly lone entrepreneurs (44\%) or joint entrepreneurs (40\%). We complemented this data with information taken from the largest professional business network, LinkedIn, which has been used in previous research (e.g., Vismara, 2016). Our human capital measure is a dummy variable to signify whether any of the entrepreneurs had previously held the role of CEO or executive director in any other businesses (e.g., Plummer et al., 2016). We followed the approach taken in previous research for our media coverage measure (e.g., Scheaf et al., 2018) and used a dichotomous variable to identify whether a new venture indicated coverage by media in their project description.

Moderator variable: In line with previous work (Eddleston et al., 2016; Johnson et al., 2018), we used a dummy variable as our gender measure, which takes the value of one if the primary entrepreneur was female. To identify the primary entrepreneur, we carefully screened all venture proposals to signify if he/she is referred to as the founder instead of co-founder, and whether he/she holds the CEO position (e.g., Geiger \& Oranburg, 2018). For gender coding, we followed best practices in female entrepreneurship and entrepreneurial finance research (e.g., Guzman \& Kacperczyk, 2019; Johnson et al., 2018). First, we manually searched for gender identifiers (he/she) in the respective venture proposal. Second, if these were ambiguous regarding the entrepreneur's gender, we looked for the 
entrepreneurs name and profile description in business plans, pitch decks, and projects description available on Crowdcube (e.g., Johnson et al., 2018). We used the genderize.io API to verify whether the name has a higher probability to belong to a female rather than a male entrepreneur (e.g., Geiger \& Oranburg, 2018). This procedure allowed us to establish a clear categorization of female and male founders.

Control variables: We controlled for nine important factors that could affect a new venture's success in equity crowdfunding. We controlled for the number of entrepreneurs involved in establishing the business, an aspect which is recognized as being important because investors equate a greater number of entrepreneurs with a greater knowledge pool (Ko \& McKelvie, 2018). The educational level of entrepreneurs is important in equity crowdfunding (Piva \& Rossi-Lamastra, 2018), and we used an education variable to denote entrepreneurs with a postgraduate degree at minimum. We used a dummy variable to indicate whether a new venture had non-executive directors as a proxy for social capital (Vismara, 2018). We further created a control variable to capture whether a new venture held a patent (Ahlers et al., 2015), which could be an important factor in a technology context. Prior financing is a critical success factor in equity crowdfunding and, in line with Kleinert et al. (2020), we used control variables to denote whether new ventures had previously raised venture capital (VC backed) or previously successfully raised crowdfunding (crowd backed). We controlled for the age of new ventures because some investors prefer more mature companies (Stuart et al., 1999). Equity retention is an essential factor in equity crowdfunding and it relates to the commitment of the entrepreneur (Vismara, 2016); therefore, we controlled for the percentage of equity offered in a campaign. Finally, we used the natural logarithm of the funding goal to control for the target amount (Ahlers et al., 2015).

\subsection{Empirical model}

Our success measures, number of investors and amount raised, are count variables. The particularities of such count variables are that they cannot take negative values and are also poisson distributed. Consequently, poisson regression would appear to be an appropriate statistical approach. However, in our case, both dependent variables are over dispersed; that is, the standard deviation is higher than the mean. Accordingly, negative binomial regression is the most appropriate model; this is a generalized poisson regression with less restrictive assumptions about the dependent variables' variance (Wooldridge, 2010). By applying this approach, we follow best practice from previous work on equity crowdfunding (e.g., Ahlers et al., 2015; Kleinert et al., 2020; Vismara, 2018). To account for heteroscedasticity, we use robust standard errors in all our models.

\section{Results}

\subsection{Descriptive statistics}

Table 1 shows the descriptive statistics. The average funding raised by a new venture in our sample is 0.57 million from around 409 investors. Standard deviations are high and suggest that success in equity crowdfunding varies widely: while some projects raised no funding or attracted only a few investors, the most successful project attracted 5253 investors and $£ 7$ million of funding. Regarding our key explanatory variables, we observe that $61 \%$ of projects were established by entrepreneurs with management experience and $33 \%$ 
Table 1 Descriptive statistics

\begin{tabular}{lrrll}
\hline Variable & Mean & \multicolumn{1}{l}{ Std } & Minimum & Maximum \\
\hline Number of investors & 408.68 & 624.00 & 10 & 5253 \\
Amount raised (in £ million) & 0.57 & 0.95 & 0.00 & 7.05 \\
Management experience & 0.61 & 0.49 & 0 & 1 \\
Media coverage & 0.33 & 0.47 & 0 & 1 \\
Female & 0.17 & 0.38 & 0 & 1 \\
Founder team size & 1.83 & 0.95 & 1 & 6 \\
Education & 0.31 & 0.46 & 0 & 1 \\
Nonexecutives & 0.26 & 0.44 & 0 & 1 \\
Patent & 0.13 & 0.33 & 0 & 1 \\
VC backed & 0.20 & 0.40 & 0 & 1 \\
Crowd backed & 0.16 & 0.37 & 0 & 1 \\
Age & 3.89 & 3.51 & 0 & 25 \\
Equity offer & 0.10 & 0.07 & 0.01 & 0.46 \\
Ln.Funding goal & 12.64 & 0.87 & 10.82 & 15.61 \\
\hline
\end{tabular}

of the ventures had previously attracted media coverage. $17 \%$ of the new ventures in our sample are female-led, which is comparable to other entrepreneurial finance contexts (e.g., Guzman \& Kacperczyk, 2019). Descriptive statistics suggest that female entrepreneurs attracted on average $£ 0.36$ million, while their male counterparts raised on average $£ 0.61$ million. Similarly, an average of 438 investors acquired shares in ventures established by men, compared to 266 investors in those established by women. The founder teams consist, on average, of two people. Ventures seeking equity crowdfunding for their technology projects tend to be relatively new (mean average of 3.89 years). A sizable number of companies had previously raised venture capital (20\%) or crowdfunding (16\%). Regarding correlations between our independent variables, we note that these are low and not of concern (see Table 4, Appendix).

\subsection{Multivariate analyses}

Tables 2 and 3 report our regression results for the dependent variables of number of investors and amount raised, respectively. Model 1 and Model 6 report the control variables only. For ease of the interpretation of coefficients, we discuss incidence rate ratios for significant variables (Wooldridge, 2010). Interestingly, we find that females in our sample of technology projects attract significantly less funding and fewer investors. Compared to male entrepreneurs, female entrepreneurs attract 0.72 of the number of investors and 0.81 of the amount raised. Overall, these findings are not surprising and are in line with the general assumptions that female entrepreneurs are more constrained than their male counterparts in terms of raising equity capital in the technology industry (Brush et al., 2018). Our measures for prior financing are additional significant control variables: previous venture capital or crowdfunding certifies the quality of a new venture, which is in line with the results presented by Kleinert et al. (2020). We also note that offering higher levels of equity correlates negatively to funding success (Vismara, 2016) and that larger funding goals are associated with greater success. This could be because new ventures at a later stage of 
Table 2 Regression results for number of investors

\begin{tabular}{|c|c|c|c|c|c|}
\hline Model & 1 & 2 & 3 & 4 & 5 \\
\hline Management experience & & $\begin{array}{l}0.38^{* * * *} \\
(0.13)\end{array}$ & $\begin{array}{l}0.5 * * * \\
(0.15)\end{array}$ & $0.37 * * *(0.13)$ & $\begin{array}{l}0.5^{* * * *} \\
(0.14)\end{array}$ \\
\hline Management experience $\times$ Female & & & $\begin{array}{l}-0.64 * * \\
(0.26)\end{array}$ & & $\begin{array}{l}-0.71 \text { *** } \\
(0.23)\end{array}$ \\
\hline Media coverage & & $\begin{array}{l}0.4 * * * \\
(0.14)\end{array}$ & $\begin{array}{l}0.41^{* * * *} \\
(0.13)\end{array}$ & $\begin{array}{l}0.29^{*} \\
(0.16)\end{array}$ & $\begin{array}{l}0.29 * \\
(0.15)\end{array}$ \\
\hline Media coverage $\times$ Female & & & & $\begin{array}{l}0.66 * * * \\
(0.26)\end{array}$ & $\begin{array}{l}0.73^{* * * *} \\
(0.25)\end{array}$ \\
\hline Female & $\begin{array}{l}-0.32^{* *} \\
(0.15)\end{array}$ & $\begin{array}{l}-0.31^{* *} \\
(0.14)\end{array}$ & $\begin{array}{l}0.17^{* * * *} \\
(0)\end{array}$ & $\begin{array}{l}-0.58^{* * *} \\
(0.17)\end{array}$ & $\begin{array}{l}-0.26 \\
(0.2)\end{array}$ \\
\hline Founder team size & $\begin{array}{l}0.05 \\
(0.07)\end{array}$ & $\begin{array}{l}0.01 \\
(0.06)\end{array}$ & $\begin{array}{l}0.03 \\
(0.06)\end{array}$ & $\begin{array}{l}0.01 \\
(0.06)\end{array}$ & $\begin{array}{l}0.03 \\
(0.06)\end{array}$ \\
\hline Education & $\begin{array}{l}0.23 \\
(0.14)\end{array}$ & $\begin{array}{l}0.29 * * \\
(0.13)\end{array}$ & $\begin{array}{l}0.28 * * \\
(0.13)\end{array}$ & $\begin{array}{l}0.31 * * \\
(0.13)\end{array}$ & $\begin{array}{l}0.3^{* *} \\
(0.12)\end{array}$ \\
\hline Nonexecutives & $\begin{array}{l}0.19 \\
(0.18)\end{array}$ & $\begin{array}{l}0.25 \\
(0.16)\end{array}$ & $\begin{array}{l}0.28^{*} \\
(0.16)\end{array}$ & $\begin{array}{l}0.27 \\
(0.17)\end{array}$ & $\begin{array}{l}0.3^{*} \\
(0.16)\end{array}$ \\
\hline Patent & $\begin{array}{l}0.1 \\
(0.16)\end{array}$ & $\begin{array}{l}0.15 \\
(0.16)\end{array}$ & $\begin{array}{l}0.19 \\
(0.16)\end{array}$ & $\begin{array}{l}0.14 \\
(0.16)\end{array}$ & $\begin{array}{l}0.17 \\
(0.16)\end{array}$ \\
\hline VC backed & $\begin{array}{l}0.37 * * \\
(0.17)\end{array}$ & $\begin{array}{l}0.41 * * \\
(0.18)\end{array}$ & $\begin{array}{l}0.45^{* *} \\
(0.18)\end{array}$ & $\begin{array}{l}0.39 * * \\
(0.17)\end{array}$ & $\begin{array}{l}0.44 * * \\
(0.17)\end{array}$ \\
\hline Crowd backed & $\begin{array}{l}0.52 * * * \\
(0.13)\end{array}$ & $\begin{array}{l}0.52 * * * \\
(0.14)\end{array}$ & $\begin{array}{l}0.52^{* * * *} \\
(0.14)\end{array}$ & $\begin{array}{l}0.53 * * * \\
(0.13)\end{array}$ & $\begin{array}{l}0.53^{* * * *} \\
(0.13)\end{array}$ \\
\hline Age & $\begin{array}{l}-0.02 \\
(0.02)\end{array}$ & $\begin{array}{l}-0.02 \\
(0.02)\end{array}$ & $\begin{array}{l}-0.02 \\
(0.02)\end{array}$ & $\begin{array}{l}-0.02 \\
(0.02)\end{array}$ & $\begin{array}{l}-0.02 \\
(0.02)\end{array}$ \\
\hline Equity offer & $\begin{array}{l}-1.72 \text { ** } \\
(0.78)\end{array}$ & $\begin{array}{l}-1.45^{* *} \\
(0.74)\end{array}$ & $\begin{array}{l}-1.51^{* *} \\
(0.74)\end{array}$ & $\begin{array}{l}-1.39 * \\
(0.72)\end{array}$ & $\begin{array}{l}-1.49^{* *} \\
(0.71)\end{array}$ \\
\hline Ln.Funding goal & $\begin{array}{l}0.53 \text { *** } \\
(0.09)\end{array}$ & $\begin{array}{l}0.48^{* * * *} \\
(0.08)\end{array}$ & $\begin{array}{l}0.46^{* * * *} \\
(0.08)\end{array}$ & $\begin{array}{l}0.49 * * * \\
(0.08)\end{array}$ & $\begin{array}{l}0.47^{* * * *} \\
(0.08)\end{array}$ \\
\hline Constant & $\begin{array}{l}-1 \\
(1.09)\end{array}$ & $\begin{array}{l}-0.73 \\
(0.99)\end{array}$ & $\begin{array}{l}-0.62 \\
(0.97)\end{array}$ & $\begin{array}{l}-0.8 \\
(0.98)\end{array}$ & $\begin{array}{l}-0.69 \\
(0.96)\end{array}$ \\
\hline Wald-chi & $163.78 * * *$ & $249.23 * * *$ & $257.62 * * *$ & $280.36 * * *$ & $320.07 * * *$ \\
\hline R-squared & 0.04 & 0.04 & 0.04 & 0.04 & 0.04 \\
\hline
\end{tabular}

$\mathrm{N}=263$. Negative binomial regression analyses, robust standard errors in parentheses

Significance levels: ${ }^{* * *} p<0.01 ; * * p<0.05 ; * p<0.10$

development seek higher levels of funding. Finally, we find that the educational level of the entrepreneur is an important factor for attracting high levels of funding.

Turning now to our hypotheses, Model 2 and Model 7 present the main effects of management experience and media coverage as hypothesized quality signals. Hypothesis 1 predicts that management experience will increase equity crowdfunding success. We find strong support for this assumption and observe that management experience increases both the number of investors and the amount raised. Equity crowdfunding projects with experienced managers have a rate 1.46 times greater for the number of investors than projects without experienced managers; similarly, such projects have a rate 1.3 times greater for the amount raised. In hypothesis 2 , we suggest that media coverage constitutes a relevant quality signal in equity crowdfunding. In support of hypothesis 2 , we find that media coverage has a strong and significant positive effect on the number of investors. Ventures with media 
Table 3 Regression results for amount raised

\begin{tabular}{|c|c|c|c|c|c|}
\hline Model & 6 & 7 & 8 & 9 & 10 \\
\hline Management experience & & $\begin{array}{l}0.27 * * \\
(0.11)\end{array}$ & $\begin{array}{l}0.39 * * * \\
(0.13)\end{array}$ & $\begin{array}{l}0.26^{* * *} \\
(0.11)\end{array}$ & $\begin{array}{l}0.38 * * * * \\
(0.13)\end{array}$ \\
\hline Management experience $\times$ Female & & & $\begin{array}{l}-0.7 * * * \\
(0.22)\end{array}$ & & $\begin{array}{l}-0.71 \text { *** } \\
(0.2)\end{array}$ \\
\hline Media coverage & & $\begin{array}{l}0.16 \\
(0.11)\end{array}$ & $\begin{array}{l}0.17 \\
(0.11)\end{array}$ & $\begin{array}{l}0.07 \\
(0.13)\end{array}$ & $\begin{array}{l}0.07 \\
(0.13)\end{array}$ \\
\hline Media coverage $\times$ Female & & & & $\begin{array}{l}0.56^{* * *} \\
(0.25)\end{array}$ & $\begin{array}{l}0.57 * * \\
(0.23)\end{array}$ \\
\hline Female & $\begin{array}{l}-0.21 * \\
(0.12)\end{array}$ & $\begin{array}{l}-0.16 \\
(0.12)\end{array}$ & $\begin{array}{l}0.17 \\
(0.15)\end{array}$ & $\begin{array}{l}-0.38^{* * *} \\
(0.13)\end{array}$ & $\begin{array}{l}-0.04 \\
(0.15)\end{array}$ \\
\hline Founder team size & $\begin{array}{l}0.05 \\
(0.06)\end{array}$ & $\begin{array}{l}0.02 \\
(0.06)\end{array}$ & $\begin{array}{l}0.04 \\
(0.06)\end{array}$ & $\begin{array}{l}0.01 \\
(0.06)\end{array}$ & $\begin{array}{l}0.04 \\
(0.06)\end{array}$ \\
\hline Education & $\begin{array}{l}0.4 * * * \\
(0.13)\end{array}$ & $\begin{array}{l}0.41 * * * \\
(0.12)\end{array}$ & $\begin{array}{l}0.41 * * * \\
(0.12)\end{array}$ & $\begin{array}{l}0.43 * * * \\
(0.12)\end{array}$ & $\begin{array}{l}0.43 * * * \\
(0.12)\end{array}$ \\
\hline Nonexecutives & $\begin{array}{l}0.16 \\
(0.14)\end{array}$ & $\begin{array}{l}0.18 \\
(0.13)\end{array}$ & $\begin{array}{l}0.21 \\
(0.13)\end{array}$ & $\begin{array}{l}0.19 \\
(0.13)\end{array}$ & $\begin{array}{l}0.22 * \\
(0.13)\end{array}$ \\
\hline Patent & $\begin{array}{l}0.2 \\
(0.16)\end{array}$ & $\begin{array}{l}0.22 \\
(0.16)\end{array}$ & $\begin{array}{l}0.27 * \\
(0.16)\end{array}$ & $\begin{array}{l}0.19 \\
(0.16)\end{array}$ & $\begin{array}{l}0.24 \\
(0.16)\end{array}$ \\
\hline VC backed & $\begin{array}{l}0.4 * * * \\
(0.15)\end{array}$ & $\begin{array}{l}0.42 * * * \\
(0.16)\end{array}$ & $\begin{array}{l}0.45 * * * \\
(0.16)\end{array}$ & $\begin{array}{l}0.43 * * * \\
(0.15)\end{array}$ & $\begin{array}{l}0.45 * * * \\
(0.15)\end{array}$ \\
\hline Crowd backed & $\begin{array}{l}0.55 * * * \\
(0.16)\end{array}$ & $\begin{array}{l}0.54 * * * \\
(0.16)\end{array}$ & $\begin{array}{l}0.52 * * * \\
(0.16)\end{array}$ & $\begin{array}{l}0.55 * * * \\
(0.16)\end{array}$ & $\begin{array}{l}0.53 * * * \\
(0.15)\end{array}$ \\
\hline Age & $\begin{array}{l}-0.01 \\
(0.02)\end{array}$ & $\begin{array}{l}-0.01 \\
(0.01)\end{array}$ & $\begin{array}{l}-0.01 \\
(0.01)\end{array}$ & $\begin{array}{l}-0.01 \\
(0.01)\end{array}$ & $\begin{array}{l}-0.01 \\
(0.01)\end{array}$ \\
\hline Equity offer & $\begin{array}{l}-1.27^{*} \\
(0.71)\end{array}$ & $\begin{array}{l}-1.11 \\
(0.69)\end{array}$ & $\begin{array}{l}-1.24^{*} \\
(0.69)\end{array}$ & $\begin{array}{l}-1.04 \\
(0.68)\end{array}$ & $\begin{array}{l}-1.2^{*} \\
(0.67)\end{array}$ \\
\hline Ln.Funding goal & $\begin{array}{l}0.91 * * * \\
(0.07)\end{array}$ & $\begin{array}{l}0.9 * * * \\
(0.07)\end{array}$ & $\begin{array}{l}0.89 * * * \\
(0.07)\end{array}$ & $\begin{array}{l}0.91 * * * \\
(0.07)\end{array}$ & $\begin{array}{l}0.9 * * * \\
(0.07)\end{array}$ \\
\hline Constant & $\begin{array}{l}0.97 \\
(0.92)\end{array}$ & $\begin{array}{l}0.95 \\
(0.88)\end{array}$ & $\begin{array}{l}0.97 \\
(0.88)\end{array}$ & $\begin{array}{l}0.87 \\
(0.88)\end{array}$ & $\begin{array}{l}0.88 \\
(0.87)\end{array}$ \\
\hline Wald-chi & $399.55^{* * *}$ & $436.55 * * *$ & $439.58 * * *$ & $456.3 * * *$ & $472.93 * * *$ \\
\hline R-squared & 0.03 & 0.03 & 0.03 & 0.03 & 0.03 \\
\hline
\end{tabular}

$\mathrm{N}=263$. Negative binomial regression analyses, robust standard errors in parentheses

Significance levels: $* * * p<0.01 ; * * p<0.05 ; * p<0.10$

coverage have a rate 1.5 times greater for the number of investors. However, media coverage does not have a significant effect on the amount raised. A potential explanation for this is that a larger number of investors might include more unsophisticated investors who invest small amounts, and it could be this type of investor who perceives media coverage as a signal of credibility. In contrast, sophisticated investors who invest larger amounts (Vismara, 2018) might perceive media coverage as a less relevant signal.

Moving on to our hypotheses 3 and 4: these predict that an investor's interpretation of signals will be subject to bias due to stereotypical perceptions. Models 3, 4, 8, and 9 report the moderation effects of management experience and media coverage according to our gender measure. In support of hypothesis 3, we find that management experience is significantly more important for male entrepreneurs than for female entrepreneurs. The effect is consistent for both dependent variables. For ease of interpretation, we use graphs to 
(a) Management experience $\mathrm{x}$ Female 600

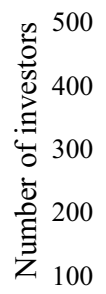

0

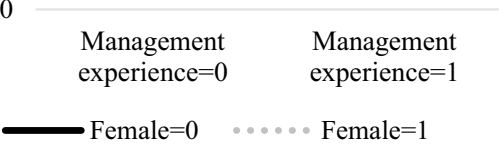

(b) Media coverage x Female 600

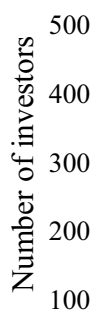

0 Media coverage $=0 \quad$ Media coverage $=1$

- Female $=0 \quad \ldots$ Female $=1$

Fig. 2 Moderation effects for number of investors

express this relationship in Figs. 2a and 3a based on the predicted margins from our regression model. Both figures highlight the econometric magnitude of this effect. While management experience increases the amount raised for male entrepreneurs by $48 \%$, it actually decreases the amount raised for female entrepreneurs: female entrepreneurs with management experience raise $15 \%$ less funding than female entrepreneurs without management experience. We also note that management experience is beneficial for male entrepreneurs in terms of increasing the number of investors by $64 \%$. For female entrepreneurs, however, it has a negative effect.

Turning to hypothesis 4 , our results provide strong support. The moderation effect between female entrepreneurs and media coverage is significant and positive for both dependent variables. Figures $2 b$ and $3 b$ visualize the econometric magnitude of the interaction effects. Media coverage helps female entrepreneurs to increase the amount raised by $86 \%$. In contrast, male entrepreneurs only increase their funding by $6.7 \%$ if their venture has media coverage. The effect of media coverage for female entrepreneurs is even greater on the number of investors, increasing this measure by $159 \%$. In contrast, media coverage increases the number of investors by only $33.5 \%$ for male entrepreneurs.

\section{Discussion}

Continuous technological advancements have changed how new ventures can acquire external capital (e.g., Audretsch et al., 2016). As such, equity crowdfunding could be a "game-changer" that facilitates access to equity capital, particularly for entrepreneurs who have struggled to fund their opportunities via traditional means of entrepreneurial finance (e.g., Walthoff-Borm et al., 2018), such as female entrepreneurs in technology sectors (Drori et al., 2018). To investigate whether equity crowdfunding can unlock this potential, we combine signaling theory (Spence, 1973) and GRCT (Eagly \& Karau, 2002). We analyze whether the gender of the signal sender moderates the effect of two important signals reflecting venture quality, i.e., management experience and media coverage. The results support our hypotheses and imply that equity crowdfunding 
(a) Management experience $x$ Female

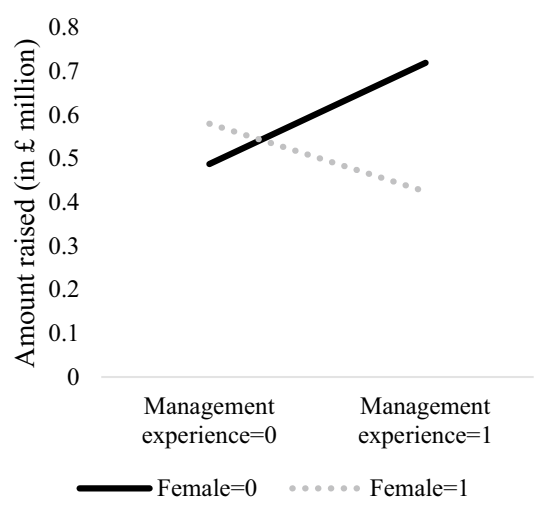

(b) Media coverage x Female

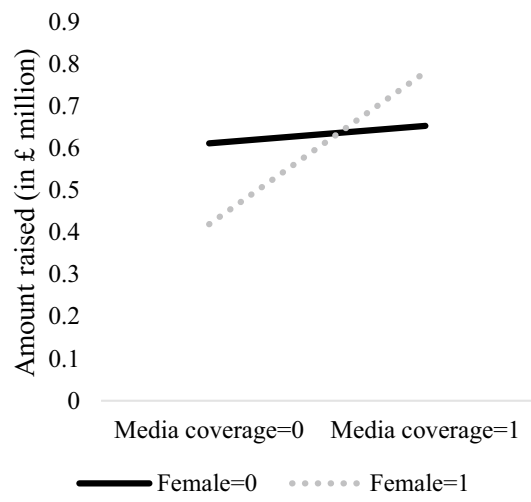

Fig. 3 Moderation effects for amount raised (in $£$ million)

investors respond differently to signals from male and female entrepreneurs. Thus, if female entrepreneurs send signals that are incongruent with their stereotypical gender role, e.g., management experience, they are less likely to be positively evaluated by equity crowdfunding investors. This effect is of considerable magnitude: even within the group of female entrepreneurs, those without management experience actually attract more funding than females with management experience. On the other hand, the signal of media coverage is beneficial for female entrepreneurs and less so for male entrepreneurs. In brief, our results indicate that if male and female entrepreneurs send signals that are congruent with their stereotypical gender roles, they are more likely to succeed in attracting equity crowdfunding. Our study also indicates that-particularly in the male-dominated domain of technology entrepreneurship-when female entrepreneurs act in accordance with their gender stereotypes, they could actually attract more funding than their male counterparts.

Although our results suggest that equity crowdfunding has the potential to increase access to external equity capital for female-led technology ventures, these results should be treated with caution. First, considering the average effect of gender on campaign success, we find that female entrepreneurs in technology raise significantly less funding and attract fewer investors. When female entrepreneurs send role incongruent signals, e.g., management experience, the negative effect becomes even more pronounced. Nevertheless, our study does provide first insights into how congruent signals, e.g., media coverage as an indication of trustworthiness, can increase the chances of female entrepreneurs in technology sectors successfully raising equity through crowdfunding campaigns.

\subsection{Theoretical and practical contributions}

Research generally shows that female entrepreneurs are, a priori, disadvantaged when competing with male entrepreneurs for traditional forms of entrepreneurial finance (e.g., Bigelow et al., 2014; Brush et al., 2018; Eddleston et al., 2016; Malmström et al., 2017). Scholars argue that equity crowdfunding holds the promise of improving access to external equity capital for female entrepreneurs (Bapna \& Ganco, 2020). To date, research 
analyzing the success potential of female entrepreneurs in equity crowdfunding has provided mixed results (e.g., Bapna \& Ganco, 2020; Geiger \& Oranburg, 2018; Vismara et al., 2017). Our study contributes to an improved understanding of the role of gender in equity crowdfunding, as called for in recent research (Butticè \& Vismara, 2021). By combining signaling theory and GRCT, we go beyond a narrow gender comparison and propose that the financing success of men and women does not simply differ as a result of preferences for male entrepreneurs. Instead, we demonstrate that investors unconsciously valorize or discount quality signals depending on whether they are congruent with gender roles. While previous research has found similar effects in traditional financing contexts that are more often to the disadvantage of women (Eddleston et al., 2016), we show that certain signals can also be more beneficial for female founders in equity crowdfunding. As such, an important finding of our study is that equity crowdfunding investors reward the same signals sent by male and female entrepreneurs differently. This is not always to the detriment of female entrepreneurs. In contrast to studies in traditional financing contexts (e.g., Brush et al., 2018; Malmström et al., 2017), our research in equity crowdfunding indicates that female entrepreneurs can even attract greater levels of financing than their male counterparts.

Further, and in contrast to previous studies, we follow the call of Johnson et al. (2018) and consider gender bias in the technology sector as a specific industry. We focus exclusively on technology ventures, a sector which is traditionally gender stereotyped as masculine and where gender bias is assumed to be of particular relevance (e.g., Brush et al., 2018; Guzman \& Kacperczyk, 2019). Overall, our findings suggest that female entrepreneurs perform worse than male entrepreneurs. Yet, our results also point out that the main effect of gender on funding performance in the technology sectors turns insignificant when considering incongruent signaling.

In terms of practical implications, our results are of interest for policymakers and actors in equity crowdfunding. Our results suggest that equity crowdfunding could be an option for mitigating the challenges faced by female entrepreneurs in the technology sector. If female entrepreneurs make the conscious decision to send signals that are congruent with their stereotyped gender role, equity crowdfunding could even become a viable form of external equity capital for their technology ventures. Therefore, female entrepreneurs should proactively acknowledge the importance of building trust in this context to increase the odds of favorable funding outcomes. However, this result indicates both, bright and dark sides, for women who seek funding via equity crowdfunding. On the one hand, our results provide insights that equity crowdfunding could under certain conditions be a valuable funding alternative for female entrepreneurs in technology sectors. On the other, our study suggests that gender stereotypes prevail in equity crowdfunding, in the way that female founders that behave according their gender stereotype will achieve more favorable campaign outcomes. Such stereotypes can never be desirable and raise concerns for equity crowdfunding platforms, investors, and policymakers, as possible discrimination prevent equal opportunities for entrepreneurs. Investors potentially even miss out promising new ventures only because entrepreneurs do not follow their expected social roles. In particular, our finding that leadership and management experience (as male-expected traits) reduces the funding success of female founders may require action; equity crowdfunding platforms may find ways to break such stereotypes. 


\subsection{Limitations and further research avenues}

Although our study provides important contributions to the literature on the role of gender in entrepreneurial finance and equity crowdfunding, it has certain limitations that lead to potentially fruitful future research avenues. First, although our study follows best practice in previous research (e.g., Kleinert et al., 2020; Piva \& Rossi-Lamastra, 2018; Vismara, 2016, 2018), our analysis suffers from the typical concerns related to observational datasets. Consequently, our findings cannot prove causation. For example, recent research highlights that equity crowdfunding platforms pre-select higher quality ventures so that our observational data might be subject to a selection bias (Kleinert et al., 2021). Therefore, we recommend that future scholars use experimental designs to increase understanding of the relationship between the gender of the entrepreneur and the effectiveness of signals. Second, our results indicate that equity crowdfunding investors reward signals sent by male and female entrepreneurs differently, but not necessarily to the detriment of women. However, our study focuses on only two important signals that display venture quality (e.g., Ko \& McKelvie, 2018; Scheaf et al., 2018). Future studies should investigate what other signals might be interpreted differently by external investors depending on the sender's gender. Third, to avoid an industry bias (Ko \& McKelvie, 2018), we focus our analysis exclusively on the technology sector, where information asymmetries and gender discrimination are particularly evident (Brush et al., 2018; Colombo et al., 2019). Thus, our results cannot be universal generalizable to ventures operating in other industries, e.g., leisure time or fashion, and might differ considering various industries. Consequently, we encourage future research to investigate gender bias in the interpretation of quality signals in additional industries. For example, research to date suggests that female entrepreneurs are more likely to attract greater levels of funding when pursuing social and sustainable entrepreneurial opportunities (e.g., Calic \& Mosakowski, 2016; Greenberg \& Mollick, 2017). Future equity crowdfunding research could therefore investigate whether signals sent by male and female entrepreneurs pursuing predominantly social or sustainable ventures are evaluated differently (Yang et al., 2020) and further consider characteristics of different investor types (Hornuf et al., 2021).

We are confident that our study provides important new nuances on how gender is embedded in the signaling process between entrepreneurs and investors. Particularly in equity crowdfunding, gender seems to play an essential role in the technology sector. However, more research is needed to clarify how gender bias may benefit both male and female entrepreneurs.

\section{Appendix}

See Table 4. 


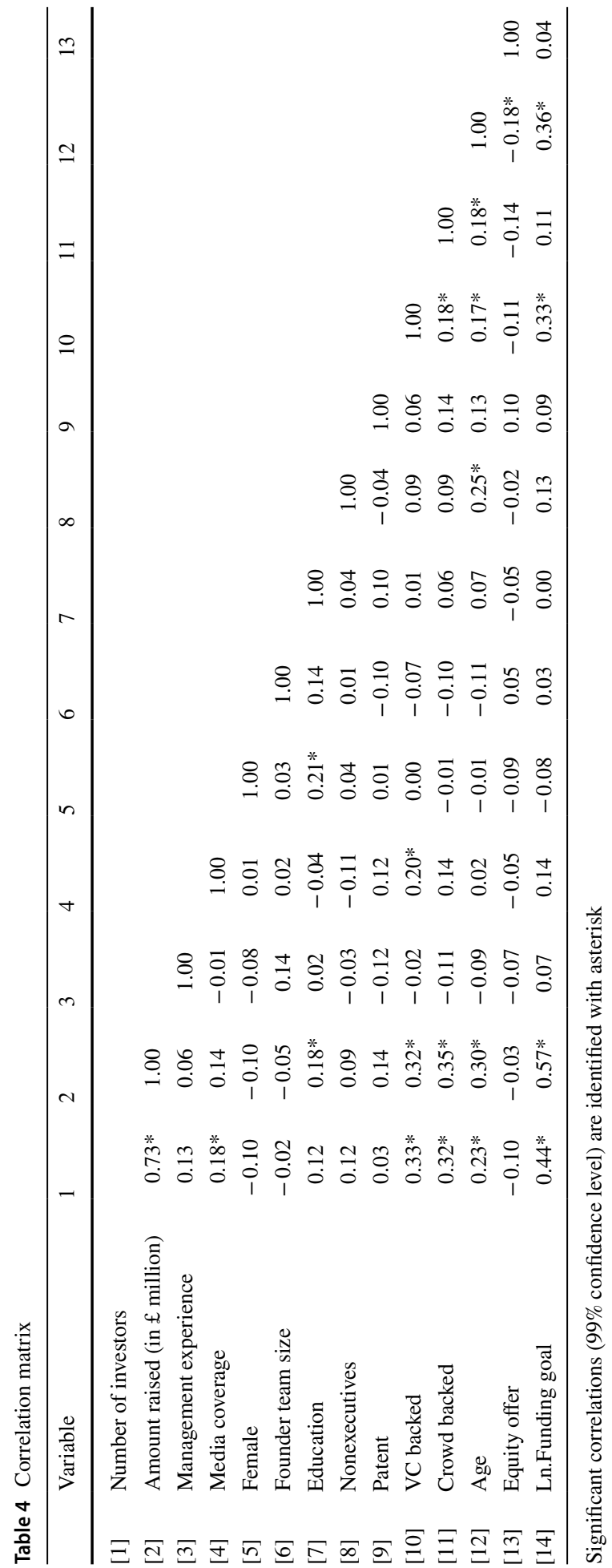


Open Access This article is licensed under a Creative Commons Attribution 4.0 International License, which permits use, sharing, adaptation, distribution and reproduction in any medium or format, as long as you give appropriate credit to the original author(s) and the source, provide a link to the Creative Commons licence, and indicate if changes were made. The images or other third party material in this article are included in the article's Creative Commons licence, unless indicated otherwise in a credit line to the material. If material is not included in the article's Creative Commons licence and your intended use is not permitted by statutory regulation or exceeds the permitted use, you will need to obtain permission directly from the copyright holder. To view a copy of this licence, visit http://creativecommons.org/licenses/by/4.0/.

\section{References}

Ahlers, G. K., Cumming, D., Günther, C., \& Schweizer, D. (2015). Signaling in equity crowdfunding. Entrepreneurship: Theory and Practice, 39(4), 955-980.

Alsos, G. A., \& Ljunggren, E. (2017). The role of gender in entrepreneur-investor relationships: A signaling theory approach. Entrepreneurship Theory and Practice, 41(4), 567-590.

Amit, R., Brander, J., \& Zott, C. (1998). Why do venture capital firms exist? Theory and Canadian evidence. Journal of Business Venturing, 13(6), 441-466.

Audretsch, D. B., Lehmann, E. E., Paleari, S., \& Vismara, S. (2016). Entrepreneurial finance and technology transfer. The Journal of Technology Transfer, 41(1), 1-9.

Bapna, S. (2019). Complementarity of signals in early-stage equity investment decisions: Evidence from a randomized field experiment. Management Science, 65(2), 933-952.

Bapna, S., \& Ganco, M. (2020). Gender gaps in equity crowdfunding: Evidence from a randomized field experiment. Management Science, 67, 1-32.

Baum, J. A., \& Silverman, B. S. (2004). Picking winners or building them? Alliance, intellectual, and human capital as selection criteria in venture financing and performance of biotechnology startups. Journal of Business Venturing, 19, 411-436.

Bigelow, L., Lundmark, L., Parks, J. M., \& Wuebker, R. (2014). Skirting the issues: Experimental evidence of gender bias in IPO prospectus evaluations. Journal of Management, 40, 1752-1753.

Block, J. H., Colombo, M. G., Cumming, D. J., \& Vismara, S. (2018a). New players in entrepreneurial finance and why they are there. Small Business Economics, 50(2), 239-250.

Block, J., Hornuf, L., \& Moritz, A. (2018b). Which updates during an equity crowdfunding campaign increase crowd participation? Small Business Economics, 50(1), 3-27.

Bosma, N., Van Praag, M., Thurik, R., \& De Wit, G. (2004). The value of human and social capital investments for the business performance of startups. Small Business Economics, 23(3), 227-236.

Brush, C., Greene, P., Balachandra, L., \& Davis, A. (2018). The gender gap in venture capital-progress, problems, and perspectives. Venture Capital, 20(2), 115-136.

Butticè, V., Di Pietro, F. \& Tenca, F. (2021). They do not look alike: What kind of private investors do equity crowdfunded firms attract. The Journal of Technology Transfer, Forthcoming.

Butticè, V., \& Vismara, S. (2021). Inclusive digital finance: The industry of equity crowdfunding. The Journal of Technology Transfer, 38, 1-18.

Calic, G., \& Mosakowski, E. (2016). Kicking off social entrepreneurship: How a sustainability orientation influences crowdfunding success. Journal of Management Studies, 53, 738-767.

Carli, L. L., \& Eagly, A. H. (2011). Gender and leadership. In A. Bryman, D. Collinson, K. Grint, B. Jackson, \& M. Uhl-Bien (Eds.), The Sage handbook of leadership (pp. 103-117). Sage Publications.

Cerpentier, M., Vanacker, T., Paeleman, I., \& Bringman, K. (2021). Equity crowdfunding, market timing, and firm capital structure. The Journal of Technology Transfer, Forthcoming.

Certo, S. T. (2003). Influencing initial public offering investors with prestige: Signaling with board structures. Academy of Management Review, 28(3), 432-446.

Cesario, J. (2014). Priming, replication, and the hardest science. Perspectives on Psychological Science, 9(1), 40-48.

Cholakova, M., \& Clarysse, B. (2015). Does the possibility to make equity investments in crowdfunding projects crowd out reward-based investments? Entrepreneurship Theory and Practice, 39(1), 145-172.

Colombo, M. G., Meoli, M., \& Vismara, S. (2019). Signaling in science-based IPOs: The combined effect of affiliation with prestigious universities, underwriters, and venture capitalists. Journal of Business Venturing, 34, 141-177.

Connelly, B. L., Certo, S. T., Ireland, R. D., \& Reutzel, C. R. (2011). Signaling theory: A review and assessment. Journal of Management, 37(1), 39-67. 
Courtney, C., Dutta, S., \& Li, Y. (2017). Resolving information asymmetry: Signaling, endorsement, and crowdfunding success. Entrepreneurship Theory and Practice, 41(2), 265-290.

Cumming, D., Meoli, M., \& Vismara, S. (2019). Does equity crowdfunding democratize entrepreneurial finance? Small Business Economics, 2019, 1-20.

Cumming, D. J., \& Vismara, S. (2017). De-segmenting research in entrepreneurial finance. Venture Capital, 19(1-2), 17-27.

Davidsson, P. (2016). Researching entrepreneurship: Conceptualization and design. Springer.

Deephouse, D. L. (2000). Media reputation as a strategic resource: An integration of mass communication and resource-based theories. Journal of Management, 26, 1091-1112.

Di Pietro, F., Grilli, L., \& Masciarelli, F. (2020). Talking about a revolution? Costly and costless signals and the role of innovativeness in equity crowdfunding. Journal of Small Business Management, 2020, 1-32.

Drori, I., Manos, R., Santacreu-Vasut, E., Shenkar, O., \& Shoham, A. (2018). Language and market inclusivity for women entrepreneurship: The case of microfinance. Journal of Business Venturing, 33(4), $395-415$.

Drover, W., Wood, M. S., \& Corbett, A. C. (2018). Toward a cognitive view of signalling theory: Individual attention and signal set interpretation. Journal of Management Studies, 55(2), 209-231.

Eagly, A. H. (1987). Sex differences in social behavior: A social-role interpretation. Erlbaum.

Eagly, A. H., \& Chin, J. L. (2010). Diversity and leadership in a changing world. American Psychologist, $65(3), 216-224$.

Eagly, A. H., \& Karau, S. J. (2002). Role congruity theory of prejudice toward female leaders. Psychological Review, 109(3), 573-598.

Eddleston, K. A., Ladge, J. J., Mitteness, C., \& Balachandra, L. (2016). Do you see what I see? Signaling effects of gender and firm characteristics on financing entrepreneurial ventures. Entrepreneurship Theory and Practice, 40(3), 489-514.

Frese, M., Krauss, S. I., Keith, N., Escher, S., Grabarkiewicz, R., Luneng, S. T., \& Friedrich, C. (2007). Business owners' action planning and its relationship to business success in three African countries. Journal of Applied Psychology, 92(6), 1481.

Geiger, M., \& Oranburg, S. C. (2018). Female entrepreneurs and equity crowdfunding in the US: Receiving less when asking for more. Journal of Business Venturing Insights, 10, e00099.

Goethner, M., Luettig, S., \& Regner, T. (2020). Crowdinvesting in entrepreneurial projects: Disentangling patterns of investor behavior. Small Business Economics, 57, 1-22.

Greenberg, J., \& Mollick, E. (2017). Activist choice homophily and the crowdfunding of female founders. Administrative Science Quarterly, 62(2), 341-374.

Gupta, V. K., Turban, D. B., Wasti, S. A., \& Sikdar, A. (2009). The role of gender stereotypes in perceptions of entrepreneurs and intentions to become an entrepreneur. Entrepreneurship Theory and Practice, 33(2), 397-417.

Guzman, J., \& Kacperczyk, A. O. (2019). Gender gap in entrepreneurship. Research Policy, 48(7), $1666-1680$.

Haeussler, C., Harhoff, D., \& Mueller, E. (2014). How patenting informs VC investors-The case of biotechnology. Research Policy, 43(8), 1286-1298.

Harrison, R. T., \& Mason, C. M. (2007). Does gender matter? Women business angels and the supply of entrepreneurial finance. Entrepreneurship Theory and Practice, 31(3), 445-472.

Heilman, M. E. (2001). Description and prescription: How gender stereotypes prevent women's ascent up the organizational ladder. Journal of Social Issues, 57, 657-674.

Higgins, M. C., \& Gulati, R. (2006). Stacking the deck: The effects of top management backgrounds on investor decisions. Strategic Management Journal, 27(1), 1-25.

Hornuf, L., Stenzhorn, E., \& Vintis, T. (2021). Are sustainability-oriented investors different? Evidence from equity crowdfunding. Journal of Technology Transfer, Forthcoming.

Hsu, D. H., \& Ziedonis, R. H. (2013). Resources as dual sources of advantage: Implications for valuing entrepreneurial-firm patents. Strategic Management Journal, 34(7), 761-781.

Islam, M., Fremeth, A., \& Marcus, A. (2018). Signaling by early stage startups: US government research grants and venture capital funding. Journal of Business Venturing, 33, 35-51.

Johnson, M. A., Stevenson, R. M., \& Letwin, C. R. (2018). A woman's place is in the... startup! Crowdfunder judgments, implicit bias, and the stereotype content model. Journal of Business Venturing, 33(6), 813-831.

Kelley, D. J., Brush, C. G., Greene, P. G., \& Litovsky, Y. (2011). Global entrepreneurship monitor (GEM) 2010 report: Women entrepreneurs worldwide. Global Entrepreneurship Monitor.

Kleinert, S., Julian, B., Urbig, D., \& Volkmann, C. (2021). Access denied: How equity crowdfunding platforms use quality signals to select new ventures. Entrepreneurship Theory and Practice, 54, 1-32. 
Kleinert, S., \& Volkmann, C. (2019). Equity crowdfunding and the role of investor discussion boards. Venture Capital, 21(4), 327-352.

Kleinert, S., Volkmann, C., \& Grünhagen, M. (2020). Third-party signals in equity crowdfunding: The role of prior financing. Small Business Economics, 54, 341-365.

Ko, E. J., \& McKelvie, A. (2018). Signaling for more money: The roles of founders' human capital and investor prominence in resource acquisition across different stages of firm development. Journal of Business Venturing, 33(4), 438-454.

Malmström, M., Johansson, J., \& Wincent, J. (2017). Gender stereotypes and venture support decisions: How governmental venture capitalists socially construct entrepreneurs' potential. Entrepreneurship Theory and Practice, 41(5), 833-860.

Mochkabadi, K., \& Volkmann, C. K. (2020). Equity crowdfunding: A systematic review of the literature. Small Business Economics, 54, 75-118.

Mousa, F. T., \& Reed, R. (2013). The impact of slack resources on high-tech IPOs. Entrepreneurship Theory and Practice, 37(5), 1123-1147.

Park, N. K., \& Mezias, J. M. (2005). Before and after the technology sector crash: The effect of environmental munificence on stock market response to alliances of e-commerce firms. Strategic Management Journal, 26(11), 987-1007.

Paustian-Underdahl, S. C., Walker, L. S., \& Woehr, D. J. (2014). Gender and perceptions of leadership effectiveness: A meta-analysis of contextual moderators. Journal of Applied Psychology, 99(6), 1129-1145.

Petkova, A. P., Rindova, V. P., \& Gupta, A. K. (2013). No news is bad news: Sensegiving activities, media attention, and venture capital funding of new technology organizations. Organization Science, 24, 865-888.

Piva, E., \& Rossi-Lamastra, C. (2018). Human capital signals and entrepreneurs' success in equity crowdfunding. Small Business Economics, 51(3), 667-686.

Plummer, L. A., Allison, T. H., \& Connelly, B. L. (2016). Better together? Signaling interactions in new venture pursuit of initial external capital. Academy of Management Journal, 59, 1585-1604.

Powell, G. N., \& Eddleston, K. A. (2015). Linking family-to-business enrichment and support to entrepreneurial success: Do female and male entrepreneurs experience different outcomes? Journal of Business Venturing, 28, 261-280.

Powell, G. N., \& Graves, L. M. (2003). Women and men in management. Sage.

Rindova, V. P., Petkova, A. P., \& Kotha, S. (2007). Standing out: How new firms in emerging markets build reputation in the media. Strategic Organization, 5, 31-70.

Scheaf, D. J., Davis, B. C., Webb, J. W., Coombs, J. E., Borns, J., \& Holloway, G. (2018). Signals’ flexibility and interaction with visual cues: Insights from crowdfunding. Journal of Business Venturing, 33, 720-741.

Shafi, K. (2019). Investors' evaluation criteria in equity crowdfunding. Small Business Economics, 56, 1-35.

Shane, S., \& Cable, D. (2002). Network ties, reputation, and the financing of new ventures. Management Science, 48(3), 364-381.

Shane, S., \& Venkataraman, S. (2000). The promise of entrepreneurship as a field of research. Academy of Management Review, 25(1), 217-226.

Spence, A. (1973). Jobmarket signaling. The Quarterly Journal of Economics, 87(3), 355-374.

Stuart, T. E., Hoang, H., \& Hybels, R. C. (1999). Interorganizational endorsements and the performance of entrepreneurial ventures. Administrative Science Quarterly, 44, 315-349.

Thébaud, S. (2015). Business as plan B: Institutional foundations of gender inequality in entrepreneurship across 24 industrialized countries. Administrative Science Quarterly, 60(4), 671-711.

Unger, J. M., Rauch, A., Frese, M., \& Rosenbusch, N. (2011). Human capital and entrepreneurial success: A meta-analytical review. Journal of Business Venturing, 26, 341-358.

Vanacker, T., Forbes, D. P., Knockaert, M., \& Manigart, S. (2020). Signal strength, media attention, and resource mobilization: Evidence from new private equity firms. Academy of Management Journal, 63(4), 1082-1105.

Vismara, S. (2016). Equity retention and social network theory in equity crowdfunding. Small Business Economics, 46(4), 579-590.

Vismara, S. (2018). Information cascades among investors in equity crowdfunding. Entrepreneurship Theory and Practice, 42(3), 467-497.

Vismara, S., Benaroio, D., \& Carne, F. (2017). Gender in entrepreneurial finance: Matching investors and entrepreneurs in equity crowdfunding. In A. N. Link (Ed.), Gender and entrepreneurial activity. Edward Elgar Publishing.

Vulkan, N., Åstebro, T., \& Sierra, M. F. (2016). Equity crowdfunding: A new phenomena. Journal of Business Venturing Insights, 5, 37-49.

Walthoff-Borm, X., Schwienbacher, A., \& Vanacker, T. (2018). Equity crowdfunding: First resort or last resort? Journal of Business Venturing, 33(4), 513-533. 
Wood, W., \& Eagly, A. H. (2010). Gender. In S. T. Fiske, D. T. Gilbert, \& G. Lindzey (Eds.), Handbook of social psychology. Oxford University Press.

Wooldridge, J. M. (2010). Econometric analysis of cross section and panel data. MIT Press.

Yang, S., Kher, R., \& Newbert, S. L. (2020). What signals matter for social startups? It depends: The influence of gender role congruity on social impact accelerator selection decisions. Journal of Business Venturing, 35(2), 105932.

Zacharakis, A. L., \& Meyer, G. D. (2000). The potential of actuarial decision models: Can they improve the venture capital investment decision? Journal of Business Venturing, 15(4), 323-346.

Zhao, Y., Xie, X., \& Yang, L. (2021). Female entrepreneurs and equity crowdfunding: The consequential roles of lead investors and venture stages. International Entrepreneurship and Management Journal, $17(3), 1183-1211$.

Publisher's Note Springer Nature remains neutral with regard to jurisdictional claims in published maps and institutional affiliations. 